\title{
Aftermath of nuclear war
}

SIR - The discussion in Nature over the past months (for example Nature 310, $621 ; 1983$ and 312,$696 ; 1984)$ of the various models and calculations on the possibility of a nuclear winter is pertinent and valid. We should like to add two points.

First, it appears that for any one aspect of nuclear war aftermath being examined in detail - be it adequacy of civil defence, food storage or distribution, world economy, fate of political and social systems and so on - the possibility for complete collapse is present in every case, and its probability usually appears quite large.

Second, the overly detailed examination of minutiae of any one model for any one aspect may serve to deflect attention and concern from the primary, unavoidable and lasting result of a major nuclear war: the death and suffering of hundreds of millions of human beings, starting milliseconds after the first flash and continuing for years and generations.

University of Oslo, PER OFTEDAL Institute of Biology, JOHN ORMEROD

Blindern,

0315 Oslo 3, Norway

SIR - We should like to comment on the continuing debate over simulation of global effects of nuclear war'. John Maddox's criticisms of the "nuclear winter" concept $\mathrm{t}^{2,3}$ were later heartily endorsed by Sherwood Idso ${ }^{4}$. However, Idso's arguments deprecating simulation techniques are grossly misleading for readers not acquainted with simulation methodology. Objections of a similar nature - namely that it is easy to programme in what wants to get out and that simulation does not prove anything - are also often raised against other studes using simulation in non-technical fields. For this reason we wish to draw attention to the question of what a simulation result in these fields can actually do.

Analysis of this problem for simulation of biological systems ${ }^{5}$ has shown that possible outcomes of simulation are: (1) survey of missing knowledge, (2) refutation of a hypothesis on which the model was constructed, (3) quantified (calibrated) model representing a more accurate hypothesis, (4) prognosis estimating future development by means of the quantified model, (5) verified model having the character of scientific explanation and (6) scientific prediction by means of the verified model.

The underlying reasoning holds also for the simulation of global effects of nuclear war. In this case a complete model verification is inconvenient. The developed models of "nuclear winter" therefore cannot be used for accurate scientific prediction and applications are limited by the first four types of outcome. A final proof demanded by Idso cannot be provided either by simulation or by any other means.

Further elaboration of models may bring about refutation, changes, refinement or further confirmation of the "nuclear winter" concept, but all this leads to enrichment of knowledge which is the aim of every scientific endeavour. The positive results of Turco et al. consist of testing plausibility of hypotheses and compatibility of assumptions and above all providing inspiration to further investigation, as has indeed been the case.

FRANTISEK HAUSER Milan Kotva

Hybrid Computation Laboratory, Institute for Social Medicine and

Organization of Health Services, Vitezného února 54.

12139 Prague, Czechoslovakia

1. Turco, R.P., Toon, O.B., Ackerman, T.P., Pollack, J.B. \& Sagan, C. Science 222, 1283-1292 (1983).

2. Maddox, J. Nature 307, 107 (1984).

3. Maddox, J. Nature 303, 11 (1984).

4. Idso, S.B. Nature 312, 407 (1948).

5. Kotva, M. in Modelling and Data Analysis in Biotechnology and Medical Engineering (eds Vansteenkiste, G.C. \& Young, P.C.) 259-267 (North-Holland, Amsterdam, 1983).

\section{Social Spencerism?}

SIR - The first edition of Nature (I have your facsimile) was published on 4 November 1869, nine months before the Franco-Prussian war which led to the political unification of Germany under Bismarck and his Kaiser. A new powerful, dynamic Germany became a major historical force through two world wars until the dissolution of Bismarckian unity in 1945 after Hitler and National Socialism. A report of a meeting of German naturalists and physicians at Innsbruck in the Tyrol prepared for the first edition of Nature by Arch. Geikie states:

What specially struck me was the universa sway which the writings of Darwin now exercise over the German mind. You see it on every side, in private conversation, in printed papers, in all the many sections into which such a meeting as that at Innsbruck divides. Darwin's name is often mentioned, and always with the profoundest veneration. But even where no allusion is specially made to him, nay, even more markedly, where such allusion is absent, we see how thoroughly his doctrines have permeated the scientific mind even in those departments of knowledge, which might seem at first sight to be furthest from natural history. "You are still discussing in England", said a German friend to me, "whether or not the theory of Darwin can be true. We have got a long way beyond that here. His theory is now our common starting point."

Herbert Spencer, a political philosopher, sociologist and friend of Darwin, who is mentioned several times in Origin of the Species, the first edition of which was produced in 1859 , persuaded Darwin to use the term "struggle for existence" in later editions ${ }^{1}$ and was to use the Darwinian ideas of "struggle for existence" and "survival of the fittest" in promoting his theories of laissez-faire capitalism which were popular especially in the United States of America until the turn of the century. Spencer was to use the authority of the great observer and thinker to bolster sociological concepts unrelated to the biological concepts of Darwin.

The confidence trick that Spencer perpetrated continues to exist in our history books where the Spencerian cuckoo is still sitting in the Darwinian nest within the arboreal history of ideas where it is known as Social Darwinism. When historians refer to "Social Darwinists" they mean militarists, nationalists, imperialists, racists or apologists for capitalism, who believe in a natural sociological pecking order which justified them morally in their use of social, economic and political power and force. It is my contention that historians are concealing and confusing issues by the use of the term "Social Darwinism" and if they must use a term of like nature they should preferably use "Social Spencerism"' Even better, let them think up some other all-embracing term since the term may be their own comparatively recent invention anyway ${ }^{1}$.

Historians call Adolf Hitler a "Social Darwinist"' . Hitler was an anti-semite, a racialist, a militarist and dictator who was unconcerned about human death and suffering. In this he was like many other men and women in history but they are not called "Social Darwinists". Hitler and his irrationalism are the antithesis of Darwin and his rationalism and I object to historians taking Darwin's name in vain. A historian of ideas ${ }^{1}$ has challenged those who believe that there was a scientific basis for National Socialism ${ }^{4}$ and that the popularization of Darwinism within Germany in the second half of the nineteenth century was partially to blame for the misdirection taken by the German nation.

The Reverend W. Tuckwell's article "Science Teaching in Schools" in the first edition of Nature reveals the state of education which preceded the Education Act passed by Gladstone in 1870 offering universal primary education in England. The nineteenth century may therefore be forgiven for not better understanding Darwin's ideas but now that they are understood, the pseudo-scientific and inherently anti-intellectual term, Social Darwinism, should be discarded.

JOHN N. BURRY

31 Hackney Road,

Hackney 5069,

South Australia, Australia

1. Kelly, A. The Descent of Darwin. The Popularization of Darwinism in Germany 1860-1914 (University of North Carolina Press, 1981).

2. Carneiro, R.L. (ed.) Introduction of Herbert Spencer: The Evolution of Society (University of Chicago Press, 1967). 3. Lacquer, W. Fascism (Penguin, Harmondsworth, 1982). 4. Gasman, D. The Scientific Origins of National Socialism: Social Darwinism in Ernst Haeckel and the German Monist League (New York, 1971). 